Article

\title{
A Bibliometric Analysis of Global Fine Roots Research in Forest Ecosystems during 1992-2020
}

\author{
Linjia Huang ${ }^{1,2}$, Ziqian $\mathrm{Xia}^{3}$ and Yang Cao ${ }^{1, * \mathbb{D}}$ \\ 1 Institute of Soil and Water Conservation, Chinese Academy of Sciences and Ministry of Water Resources, \\ Yangling, Xianyang 712100, China; huanglinjia20@mails.ucas.ac.cn \\ 2 University of Chinese Academy of Sciences, Beijing 100049, China \\ 3 School of Qianhu, Nanchang University, Nanchang 330031, China; Ziqian.research@gmail.com \\ * Correspondence: yang.cao@nwsuaf.edu.cn
}

check for

updates

Citation: Huang, L.; Xia, Z.; Cao, Y. A Bibliometric Analysis of Global Fine Roots Research in Forest Ecosystems during 1992-2020. Forests 2022, 13, 93. https://doi.org/10.3390/f13010093

Academic Editor: Douglas Godbold

Received: 27 November 2021

Accepted: 4 January 2022

Published: 10 January 2022

Publisher's Note: MDPI stays neutral with regard to jurisdictional claims in published maps and institutional affiliations.

Copyright: () 2022 by the authors Licensee MDPI, Basel, Switzerland. This article is an open access article distributed under the terms and conditions of the Creative Commons Attribution (CC BY) license (https:// creativecommons.org/licenses/by/ $4.0 /)$.

\begin{abstract}
Background: Fine roots ( $\leq 2 \mathrm{~mm}$ in diameter) play a critical role in forest ecosystem ecological processes and has been widely identified as a major research topic. This study aimed to synthesize the global literature based on the Web of Science Core Collection scientific database from 1992 to 2020 and summarize the research trends and prospects on research of fine roots in forest ecosystems. A quantitative bibliometric analysis was presented with information related to authors, countries, institutions, journals, top cited publications, research hotspots, trends, and prospects. (2) Results: The results showed that the amount of publications has increased exponentially. USA, China, and Germany were the most productive countries. Chinese Academy of Science was the most productive institution on fine roots research and also has a key position in both domestic and international cooperation networks. Leuschner $\mathrm{C}$ and Hertel $\mathrm{D}$ were the most productive authors. Six core journals were confirmed from 471 journals based on Bradford's law. The distribution of the frequency of authors and the number of their publications were fitted with Lotka's Law. Author collaboration network was mainly limited in the same countries/territories and institutions. Keywords analysis indicates that the hotspots are biomass, decomposition, and respiration of fine roots, especially under climate change. (3) Conclusion: Our results provide a better understanding of global characteristics and trends of fine roots that have emerged in this field, which could offer reference for future research.
\end{abstract}

Keywords: citations; core journals; knowledge mapping; network analysis; Lotka's Law; VOS viewer

\section{Introduction}

Fine roots, traditionally defined as a diameter of less than $2 \mathrm{~mm}$, are the most active part of belowground mass and play key roles in forest ecosystem processes [1,2]. The major function of fine roots is to uptake water and nutrients from the surrounding soil, which is subsequently transported to aboveground parts for storage, photosynthesis, and growth needs. Fine roots production is estimated to constitute about one-third of global annual net primary production, while fine root biomass contributes relatively little $(0.5-10 \%)$ to total forest biomass [1,3-5]. Moreover, fine roots account for a substantial amount (33\%) of litter inputs in forest ecosystems, and fine root decomposition contributes significantly to carbon and nutrient cycling by mineralizing and releasing nutrients for plant and microbial uptake [6-9]. The amount of carbon and nutrients returned to the soil through the fine roots is equal to or even higher than that of leaf litter owing to the rapid turnover rate $[10,11]$. For example, $70 \%$ of the soil $\mathrm{C}$ stock in some forests is derived from fine roots and their associated microorganisms [12,13]. Furthermore, fine roots have potential utility as indicators of environmental stress and change, such as tree health status, forest management, soil pollution, and climate change [14-18]. Thus, in view of the prominent role of fine roots in biology, physiology, biogeochemical cycling, and plant-soil-microbe 
interactions in forest ecosystem structure and functions, there was extensive research on this exciting and intriguing topic and the body of research continues to grow rapidly.

Increasing numbers of international scholars have conducted research on fine root biology to understand the development and functions of fine roots in forest ecosystems. Although enough empirical and qualitative articles by experts have offered overview and synthesis of fine roots research in forest ecosystems, they are limited in some specific aspects, such as, functional traits, regions, methodologies, and database [2,6,19-22]. Thus, traditional review articles are limited in their capacity to assess large volumes of diverse literature and cannot provide an effectively organized and summarized development of a specific research field among a large amount of studies on large spatial and temporal scales, and trends and ideas for future researchers [23,24]. To this end, bibliometric analysis is urgently needed in order to create a comprehensive overview of the study of fine roots research in forest ecosystems.

Bibliometric analysis is a modern research assessment method, based on the basic theory of bibliometric. It uses statistical mathematics to analyze, describe, and visualize the literature in relevant research fields. It thus allows to provide a new perspective regarding knowledge status, features, and to predict the research trends of specific topics [25]. It can help fresh researchers and interested policy makers to quickly obtain the basic status of this field and discover trends [26,27]. Bibliometric analysis includes the qualitative and quantitative analysis of publications indexed by databases based on statistics and computing technology, collaborations among different journals, countries and institutions, co-authorship and co-occurring categories, and keywords [25]. This technique has been widely applied in research topics such as agroforestry, soil health, microplastics, forest entrepreneurship, climate change and carbon sink, ecological restoration, and other disciplines [24,27-33]. Moreover, it is also used to investigate research trends in some specific regions, i.e., Arctic Region and the Chinese Loess Plateau [26,34]. Therefore, bibliometric analysis can be used in management and decision-making processes in science and technology [31].

In order to provide a systemic and objective overview of the scientific research development of fine roots in forest ecosystems, this study identifies bibliometric characteristics and visualizes relationships between articles in this field published in the journals of Web of Science Core Collection to fill this research gap and facilitate a better understanding of trends and prospects of fine root research. The goals of this study include the following aspects: (1) identifying the basic characteristics of the publication, such as the number of publications and citations, representative countries, journals, institutions, authors and research subjects; (2) recognizing the knowledge base according to common cited references; (3) uncovering changing trends in research topics and hotspots over time; and, (4) identifying opportunities for future research.

\section{Materials and Methods}

\subsection{Data Collection}

The data used in this study was obtained from the Web of Science Core Collection (Clarivate Analytics) database from its inception to 2020, using the following search strategy: TOPIC $=($ "fine root *" AND (forest * or plantation *)), including all language and all document types in the first step. As a result, the retrieval data with a total of 3694 research papers were selected, containing $3653(98.89 \%)$ in English. Among these English papers, article $(3299,90.31 \%)$ is the most active document type, followed by reviews $(151,4.13 \%)$. Considering the representativeness, we focused on the analysis and evaluation of these two types of papers in this study. We recruited 3310 papers based on our inclusion criteria. Thus, these 3310 records with selected information (including title, keywords, abstract, introduction, author information, journals, citation, and institutional affiliation) were extracted as data for further analysis. The final search for papers was carried out in April 2021. The diagram of the study process is shown in Figure S1 of Supplementary Material. 


\subsection{Bibliometric Analysis}

The Web of Science platform can provide a basic result analysis tool that can be utilized for preliminary analysis, such as: number of publications per year, number of publications per country, number of publications per institution, number of publications per author, number of citations per article, number of publications per journal, and other variables. Meanwhile, it can also provide some indicators, i.e., impart factor (IF) and h-index, to show the performance of various journals, countries, institutions, and authors. Impact factor is an indicator used to rank and evaluate journals in the process of academic evaluation and to provide an objective comparison between journals. h-index is an indicator for the evaluation of academic influence of journals, countries/territories, and institutes from both quality and quantity perspectives. Moreover, several bibliometric tools were used to conduct in-depth data analysis, including the 'bibliometrix' package in $\mathrm{R}$ (version 4.0.0, $\mathrm{R}$ Core Team) and VOSViewer software (version 2.6.5, Leiden University, Leiden, The Netherlands).

The bibliometrix R-package (http: / / www.bibliometrix.org (accessed on 8 October 2011)) provides a set of novel and unique tools for quantitative research in bibliometrics and scientometrics [35]. The bibliometrix package offers a series of routines to import bibliographic data and carry out bibliometric analyses through inferences on indicators. In addition, as the bibliometrix package can be integrated with other R-packages, it will expand the measurement capabilities of bibliometrix, embedding machine learning and deep learning algorithms, to enrich data interpretation [36]. VOSviewer, available at http://www.vosviewer.com (accessed on 8 October 2011) is a free bibliometric visualizer with an intuitive and user-friendly interface [37]. VOSviewer can construct and visualize the relationship between literature knowledge units to show the structure, evolution, cooperation, and other relations. It can also provide text mining functions to construct and visualize co-occurrence networks of important terms extracted from a large number of scientific documents. VOSviewer can be used to construct social networks for the author's networks, keyword networks, cited networks, and institutional network based on co-authorship, co-occurrence, citation, bibliographic coupling, and co-citation links.

\section{Results and Discussion}

\subsection{General Statistics}

The first 33 studies were recorded in the database in 1992, and then the annual number of publications increased to 199 in 2020 (Figure 1a). The exponential growth $\left(R^{2}=0.95\right)$ of the number of publications over the years is in line with the Price law of scientific literature growth (Figure 1a). It was clear that this trend was mainly due to the growing awareness of the important functions of fine roots in forest ecosystems. This positive growth trend agrees with the general trend in many research fields [34,38]. All publications received 144,930 total citations and 43.59 citations per publication, reaching an h-index of 161.
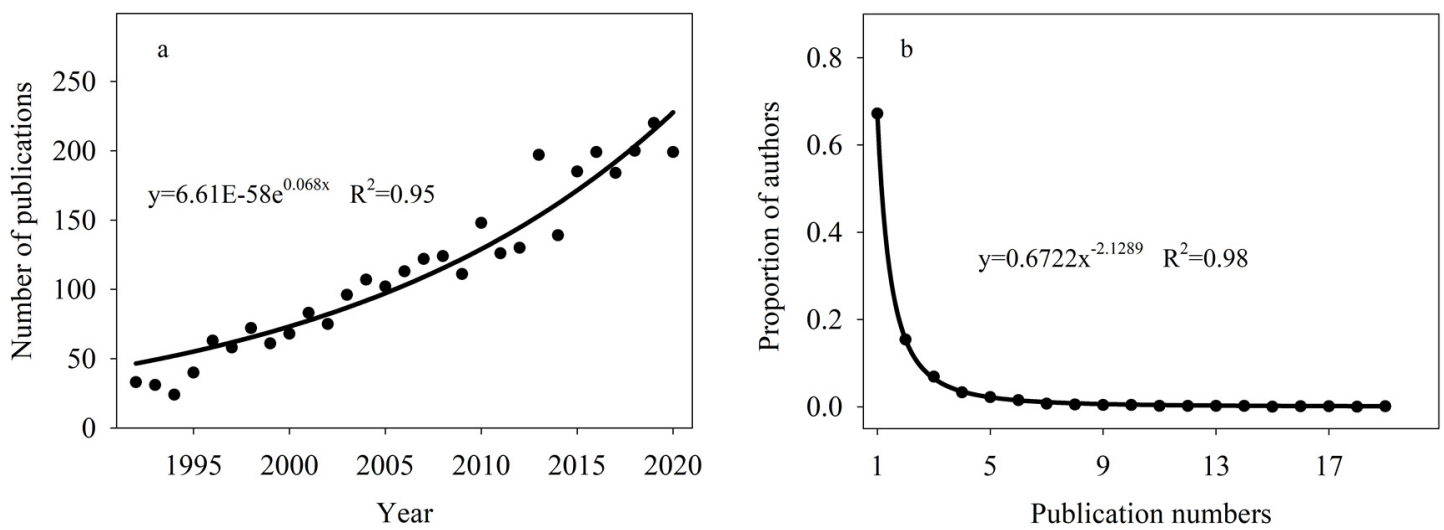

Figure 1. Number of related publications in Web of Science from 1992-2020 (a) and the frequency distribution of author scientific productivity (b). 
All the selected papers were from 1971 institutions of 102 countries, among which United States of America (USA) is the most productive country $(1175,35.50 \%)$, mainly contributed by United States Forest Service (Table 1). China (663, 20.03\%) ranks second with the highest contribution from Chinese Academy of Sciences, followed by Germany (390, 11.78\%, mainly from University of Göttingen). Meanwhile, the USA held the highest h-index (143) and total citation $(81,621)$, followed by the Germany, Sweden, and China (Table 1). A similar gap was also observed in institutes among countries (Table 1). These results indicate that developed countries and their institutes have significant contributions to the development of this field because they can invest more resources in natural science research. Despite substantial total publications, the lower h-index and total citations in China and their institutes indicate that the research findings and outcomes from China might be less novel and important, and thus more efforts still should be engaged for improving academic influence. Those results were also observed in other research fields [23,24,38]. Thus, novel and important research findings should be considered to improve academic influence rather than the number of publications.

Table 1. The top 10 most productive countries and institutes.

\begin{tabular}{|c|c|c|c|c|c|c|c|c|}
\hline Rank & Country & N (\%) & Citations & $h$-Index & Institution & N (\%) & Citations & $h$-Index \\
\hline 1 & USA & $\begin{array}{c}1175 \\
(35.50 \%)\end{array}$ & 81,621 & 143 & $\begin{array}{l}\text { Chinese Academy of } \\
\text { Sciences, China }\end{array}$ & $\begin{array}{c}307 \\
(9.27 \%)\end{array}$ & 7073 & 38 \\
\hline 2 & China & $\begin{array}{c}663 \\
(20.03 \%)\end{array}$ & 14,641 & 53 & $\begin{array}{l}\text { United States Forest } \\
\text { Service, USA }\end{array}$ & $\begin{array}{c}143 \\
(4.32 \%)\end{array}$ & 9119 & 49 \\
\hline 3 & Germany & $\begin{array}{c}390 \\
(11.78 \%)\end{array}$ & 19,491 & 67 & $\begin{array}{c}\text { Swedish University } \\
\text { of Agricultural } \\
\text { Science, Sweden }\end{array}$ & $\begin{array}{c}129 \\
(3.89 \%)\end{array}$ & 6919 & 46 \\
\hline 4 & Canada & $\begin{array}{c}263 \\
(7.95 \%)\end{array}$ & 9703 & 51 & $\begin{array}{l}\text { University of } \\
\text { Göttingen, Germany }\end{array}$ & $\begin{array}{c}123 \\
(3.72 \%)\end{array}$ & 6543 & 42 \\
\hline 5 & Japan & $\begin{array}{c}197 \\
(5.95 \%)\end{array}$ & 4999 & 37 & $\begin{array}{l}\text { University of } \\
\text { Chinese Academy of } \\
\text { Sciences, China }\end{array}$ & $95(2.87 \%)$ & 1216 & 20 \\
\hline 6 & Sweden & $\begin{array}{c}195 \\
(5.89 \%)\end{array}$ & 10,089 & 56 & $\begin{array}{c}\text { Cornell University, } \\
\text { USA }\end{array}$ & $85(2.57 \%)$ & 6146 & 38 \\
\hline 7 & France & $\begin{array}{c}180 \\
(5.44 \%)\end{array}$ & 8957 & 46 & $\begin{array}{c}\text { University of } \\
\text { Helsinki, Finland }\end{array}$ & $79(2.39 \%)$ & 3699 & 30 \\
\hline 8 & Australia & $\begin{array}{c}151 \\
(4.56 \%)\end{array}$ & 7164 & 44 & INRAE, France & $76(2.29 \%)$ & 3848 & 32 \\
\hline 9 & Finland & $\begin{array}{c}150 \\
(4.53 \%)\end{array}$ & 7325 & 46 & $\begin{array}{l}\text { Kyoto University, } \\
\text { Japan }\end{array}$ & $72(2.17 \%)$ & 1545 & 21 \\
\hline 10 & Switzerland & $\begin{array}{c}147 \\
(4.44 \%)\end{array}$ & 5845 & 40 & $\begin{array}{c}\text { Duke University, } \\
\text { USA }\end{array}$ & $66(1.99 \%)$ & 9728 & 48 \\
\hline
\end{tabular}

There were 8224 authors in the recorded documents. The mean number of articles per author was 0.402 and there were 114 documents with only one author. Leuschner $C$ was the most productive author with 67 research papers since 1994 while ranked 2nd in terms of h-index (Table 2 and Figure S2). Pregitzer KS ranked No.1 with respect to h-index, but ranked 3rd in terms of the total publications since 1992 (Table 2 and Figure S2). Hertel D was the second influential researcher in terms of quantity (59 publications since 2001) and quality ( $h$-index $=30)$. Moreover, among those 8224 authors, $5526(67.19 \%)$ appeared in one article, followed by 1264 (15.37\%) in two, 569 (6.92\%) in three, 273 (3.32\%) in four, and 178 $(2.16 \%)$ appeared in five articles. This indicated that many researchers were involved in relevant work, but only a small number of authors focused on this research area for a long time. The distribution of the frequency of authors and the number of their publications of the present research field significantly conforms to the Lotka's Law (Figure 1b). Generally, Lotka's Law, a classic bibliometric law, describes the frequency of publications by authors in a given discipline [39]. The exponent and constant parameters could be influenced by the subject area and its productivity, country, study period, and length [36]. 
Table 2. The top 10 most productive authors and co-cited authors.

\begin{tabular}{|c|c|c|c|c|c|c|}
\hline Rank & $\begin{array}{l}\text { Productive Author } \\
\text { (Affiliate) }\end{array}$ & N (\%) & Citations & $h$-Index & $\begin{array}{l}\text { Co-Cited Author } \\
\text { (Affiliate) }\end{array}$ & Co-Citations \\
\hline 1 & $\begin{array}{l}\text { Leuschner C } \\
\text { (University of } \\
\text { Göttingen, } \\
\text { Germany) }\end{array}$ & $67(2.02 \%)$ & 2902 & 31 & $\begin{array}{c}\text { Vogt KA } \\
\text { (University of } \\
\text { Washington, USA) }\end{array}$ & 1312 \\
\hline 2 & $\begin{array}{l}\text { Hertel D } \\
\text { (University of } \\
\text { Göttingen, } \\
\text { Germany) }\end{array}$ & $59(1.78 \%)$ & 2557 & 30 & $\begin{array}{l}\text { Pregitzer KS } \\
\text { (University of } \\
\text { Idaho, USA) }\end{array}$ & 1194 \\
\hline 3 & $\begin{array}{l}\text { Pregitzer KS } \\
\text { (University of } \\
\text { Idaho, USA) }\end{array}$ & $53(1.60 \%)$ & 6365 & 40 & $\begin{array}{c}\text { Jackson RB. } \\
\text { (Stanford } \\
\text { University, USA) }\end{array}$ & 788 \\
\hline 4 & $\begin{array}{l}\text { Fahey TJ (Cornell } \\
\text { University, USA) }\end{array}$ & $49(1.48 \%)$ & 3816 & 29 & $\begin{array}{c}\text { Norby RJ (Oak } \\
\text { Ridge National } \\
\text { Laboratory, USA) }\end{array}$ & 762 \\
\hline 5 & $\begin{array}{c}\text { Helmisaari HS } \\
\text { (University of } \\
\text { Helsinki, Finland) }\end{array}$ & $36(1.08 \%)$ & 1983 & 25 & $\begin{array}{c}\text { Eissenstat DM } \\
\text { (Pennsylvania State } \\
\text { University, USA) }\end{array}$ & 757 \\
\hline 6 & $\begin{array}{l}\text { Chen HYH } \\
\text { (Lakehead } \\
\text { University, } \\
\text { Canada) }\end{array}$ & $35(1.05 \%)$ & 1600 & 20 & $\begin{array}{l}\text { Hendrick RL (Ohio } \\
\text { State University, } \\
\text { USA) }\end{array}$ & 691 \\
\hline 7 & $\begin{array}{l}\text { Zak DR (University } \\
\text { of Michigan, USA) }\end{array}$ & $35(1.05 \%)$ & 3098 & 26 & $\begin{array}{l}\text { Nadelhoffer KJ } \\
\text { (University of } \\
\text { Michigan, USA) }\end{array}$ & 690 \\
\hline 8 & $\begin{array}{l}\text { Brunner I (Swiss } \\
\text { Federal Institute for } \\
\text { Forest, } \\
\text { Switzerland) }\end{array}$ & $33(0.99 \%)$ & 1264 & 17 & $\begin{array}{c}\text { Vitousek PM } \\
\text { (Stanford } \\
\text { University, USA) }\end{array}$ & 645 \\
\hline 9 & $\begin{array}{l}\text { Jourdan C } \\
\text { (Universite de } \\
\text { Montpellier, } \\
\text { France) }\end{array}$ & $33(0.99 \%)$ & 1113 & 20 & $\begin{array}{c}\text { Reich PB } \\
\text { (University of } \\
\text { Minnesota System, } \\
\text { USA) }\end{array}$ & 640 \\
\hline 10 & $\begin{array}{c}\text { Norby RJ(Oak } \\
\text { Ridge National } \\
\text { Laboratory, USA) }\end{array}$ & $33(0.99 \%)$ & 4676 & 28 & $\begin{array}{c}\text { Raich JW (Lowa } \\
\text { State University, } \\
\text { USA) }\end{array}$ & 635 \\
\hline
\end{tabular}

"A Global Analysis of Root Distributions for Terrestrial Biomes", a study conducted by Jackson et al. (1996) [40] published in Oecologia, was the most cited article, with 1706 citations and an average of 65.62 citations per year (Table 3). In this study, the authors compiled a global database of 250 root studies and analyzed root distribution for 11 terrestrial biomes. A new study published by Reich (2014) [41] in the Journal of Ecology was the most cited article per year (143.13), while it is ranked 3rd in total citations so far (Table 3). Thus, the most cited articles can provide helpful insights to researchers interested in this field. Moreover, two important indicators, local citation score (LCS) and global citation score (GCS), were used to identify hot publications with citations analysis. GCS refers to the total number of citations in the Web of Science database. LCS represents the number of times a document has been cited in the current sample literature (Vargas et al., 2019) [42]. The publication with the highest academic influence in the current research field was "A Global Budget for Fine Root Biomass, Surface Area, and Nutrient Contents", written by Jackson et al. (1997) [6] with LCS of 384 and GCS of 891 (Table 3). Compared to other publications with high LCS and those with high GCS, Jackson et al. (1996) [40] and Silver and Miya (2001) [43] had high GCS but relatively low LCS (Table 3). This indicated that their citations were mainly from research in other fields. 
Table 3. The top 10 most cited, co-cited, and local citation score publications.

\begin{tabular}{|c|c|c|c|c|c|c|c|}
\hline Rank & $\begin{array}{c}\text { Cited } \\
\text { Publications }\end{array}$ & Citations & $\begin{array}{c}\text { Co-Cited } \\
\text { Publications }\end{array}$ & $\begin{array}{c}\text { Co- } \\
\text { Citations }\end{array}$ & $\begin{array}{l}\text { Local Citation } \\
\text { Score } \\
\text { Publications }\end{array}$ & LCS & GCS \\
\hline 1 & $\begin{array}{l}\text { A global analysis } \\
\text { of root } \\
\text { distributions for } \\
\text { terrestrial biomes } \\
\text { (Jackson RB, } \\
\text { 1996, Oecologia) }\end{array}$ & 1706 & $\begin{array}{l}\text { A global } \\
\text { budget for fine } \\
\text { root biomass, } \\
\text { surface area, } \\
\text { and nutrient } \\
\text { contents } \\
\text { (Jackson RB, } \\
\text { 1997, P Natl } \\
\text { Acad Sci USA) }\end{array}$ & 389 & $\begin{array}{l}\text { A global budget } \\
\text { for fine root } \\
\text { biomass, surface } \\
\text { area, and } \\
\text { nutrient contents } \\
\text { (Jackson RB, } \\
\text { 1997, P Natl } \\
\text { Acad Sci USA) }\end{array}$ & 384 & 891 \\
\hline 2 & $\begin{array}{c}\text { Soil water } \\
\text { content and } \\
\text { temperature as } \\
\text { independent or } \\
\text { confounded } \\
\text { factors } \\
\text { controlling soil } \\
\text { respiration in a } \\
\text { temperate mixed } \\
\text { hardwood forest } \\
\text { (Davidson EA, } \\
\text { 1998, Glob } \\
\text { Change Biol) }\end{array}$ & 1289 & $\begin{array}{l}\text { Fine root } \\
\text { architecture of } \\
\text { nine North } \\
\text { American trees } \\
\text { (Pregitzer KS, } \\
\text { 2002, Ecol } \\
\text { Monogr) }\end{array}$ & 310 & $\begin{array}{l}\text { Global patterns } \\
\text { of root turnover } \\
\text { for terrestrial } \\
\text { ecosystems } \\
\text { (Gill RA, 2000, } \\
\text { New Phytol) }\end{array}$ & 299 & 733 \\
\hline 3 & $\begin{array}{l}\text { The world-wide } \\
\text { 'fast-slow' plant } \\
\text { economics } \\
\text { spectrum: a traits } \\
\text { manifesto } \\
\text { (Reich PB, 2014, J } \\
\text { Ecol) }\end{array}$ & 1145 & $\begin{array}{l}\text { Global patterns } \\
\text { of root } \\
\text { turnover for } \\
\text { terrestrial } \\
\text { ecosystems } \\
\text { (Gill RA, 2000, } \\
\text { New Phytol) }\end{array}$ & 301 & $\begin{array}{c}\text { The ecology of } \\
\text { root lifespan } \\
\text { (Eissenstat DM, } \\
\text { 1997, Adv Ecol } \\
\text { Res) }\end{array}$ & 227 & 550 \\
\hline 4 & $\begin{array}{l}\text { A global budget } \\
\text { for fine root } \\
\text { biomass, surface } \\
\text { area, and } \\
\text { nutrient contents } \\
\text { (Jackson RB, } \\
\text { 1997, P Natl } \\
\text { Acad Sci USA) }\end{array}$ & 891 & $\begin{array}{l}\text { Review of root } \\
\text { dynamics in } \\
\text { forest } \\
\text { ecosystems } \\
\text { grouped by } \\
\text { climate, } \\
\text { climatic forest } \\
\text { type and } \\
\text { species } \\
\text { (Vogt KA, 1996, } \\
\text { Plant Soil) }\end{array}$ & 257 & $\begin{array}{c}\text { Fine root } \\
\text { production } \\
\text { estimates and } \\
\text { belowground } \\
\text { carbon allocation } \\
\text { in forest } \\
\text { ecosystems } \\
\text { (Nadelhoffer KJ, } \\
\text { 1992, Ecology) }\end{array}$ & 205 & 337 \\
\hline 5 & $\begin{array}{c}\text { Deep soil organic } \\
\text { matter-a key but } \\
\text { poorly } \\
\text { understood } \\
\text { component of } \\
\text { terrestrial C cycle } \\
\text { (Rumpel C, 2011, } \\
\text { Plant Soil) }\end{array}$ & 757 & $\begin{array}{l}\text { The role of fine } \\
\text { roots in the } \\
\text { organic matter } \\
\text { and nitrogen } \\
\text { budgets of two } \\
\text { forested } \\
\text { ecosystems } \\
\text { (McClaugherty } \\
\text { CA, 1982, } \\
\text { Ecology) }\end{array}$ & 240 & $\begin{array}{c}\text { The demography } \\
\text { of fine roots in a } \\
\text { northern } \\
\text { hardwood forest } \\
\text { (Hendrick RL, } \\
\text { 1992, Ecology) }\end{array}$ & 190 & 315 \\
\hline
\end{tabular}


Table 3. Cont.

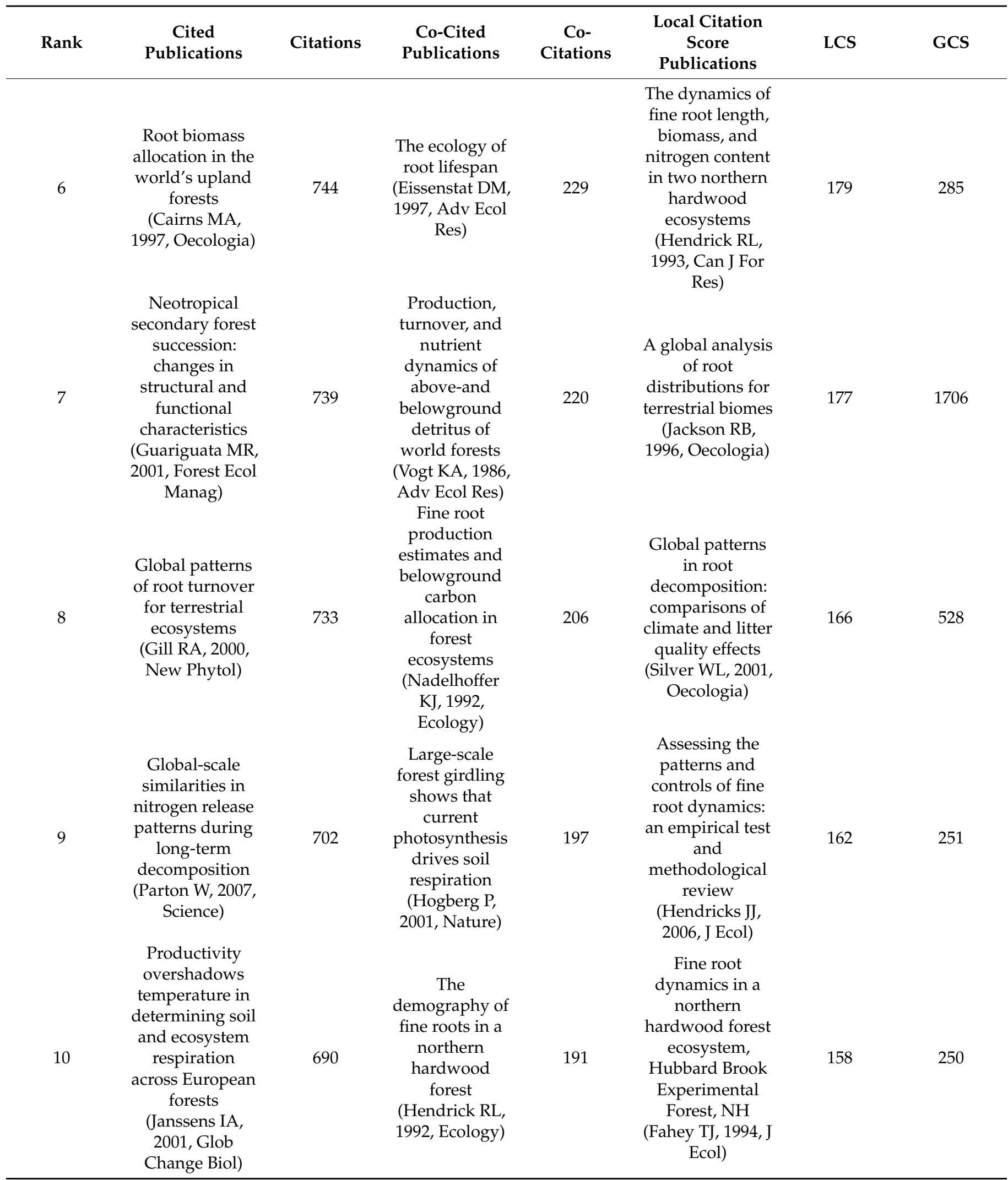

Note: LCS: local citation score, GCS: Global citation score.

The selected articles were published in 471 journals. There was a clear imbalance in the journals that publish fine roots research, and only a few journals have been paying attention 
to the progress of fine roots research in forest ecosystem. Plant and Soil had the highest number of published articles, accounting for $9.70 \%$ of the total published, closely followed by Forest Ecology and Management, publishing over three hundreds articles (Table 4 and Figure S3). The annual publication of Plant and Soil and Forest Ecology and Management were obviously more than other journals, but the annual publication of a new open access journal of Forest significantly increased from its start year and reached the highest number in 2020 among the journals (Figure S3). Forest Ecology and Management, Global Change Biology, and New Phytologist had the higher academic influence in term of total citations and h-index. Global Change Biology and New Phytologist had an obvious higher impact factor (Table 4). Moreover, according to Bradford's law, journals in a research topic can be divided into three parts: core journals, relevant journals, and non-related journals by arranging all journals in descending order according to the number of publications [44]. The top six most productive journals were selected as core journals, and then 25 journals, such as Oecologia, Forests, Ecosystem, Canadian Journal of Forest Research, Biogeochemistry, Ecology, Plos One, Trees, Journal of Ecology, were selected as relevant journals and the rest were non-related journals (Table 4).

Table 4. The top ten most productive journals.

\begin{tabular}{|c|c|c|c|c|c|}
\hline Rank & Journal Name & N (\%) & $h$-Index & Citation & $\begin{array}{c}\text { Impact } \\
\text { Factor (2019) }\end{array}$ \\
\hline 1 & $\begin{array}{l}\text { Plant and Soil } \\
\text { Forest Ecology }\end{array}$ & $321(9.70 \%)$ & 50 & 9866 & 3.299 \\
\hline 2 & Mand & $304(9.18 \%)$ & 60 & 12,820 & 3.17 \\
\hline 3 & $\begin{array}{l}\text { Soil Biology } \\
\text { Biochemistry }\end{array}$ & $123(3.72 \%)$ & 40 & 4598 & 5.795 \\
\hline 4 & $\begin{array}{c}\text { Global Change } \\
\text { Biology }\end{array}$ & $122(3.70 \%)$ & 60 & 13,499 & 8.512 \\
\hline 5 & New Phytologist & $121(3.66 \%)$ & 56 & 10,610 & 8.555 \\
\hline 6 & Tree Physiology & $119(3.60 \%)$ & 43 & 6186 & 3.655 \\
\hline 7 & Oecologia & $85(2.60 \%)$ & 45 & 8539 & 2.654 \\
\hline 8 & Forests & $78(2.36 \%)$ & 10 & 586 & 2.221 \\
\hline 9 & $\begin{array}{c}\text { Ecosystems } \\
\text { Canadian }\end{array}$ & $76(2.30 \%)$ & 34 & 3679 & 4.207 \\
\hline 10 & $\begin{array}{c}\text { Journal of Forest } \\
\text { Research }\end{array}$ & $72(2.18 \%)$ & 30 & 2329 & 1.812 \\
\hline
\end{tabular}

\subsection{Co-Authorship Network Analysis}

Co-authorship mapping and clustering are essential indicator factors for scientific collaboration between co-authors [39]. Analysis reveals the social structure of the set network by identifying participants and their connections. Authors who are closely connected are clustered into a group. To reduce the complexity of the networks and improve their readability, we set the minimum number of corporation number documents of an author as 10; of the 8224 authors, 93 authors met the threshold. For each of the 93 authors, the total strength of the co-authorship links with other authors was calculated. The authors with the greatest total link strength were selected. Only 56 authors had corporation, and can be grouped into eleven categories by cluster analysis, where each cluster is marked by a different color (Figure 2). It is noted that the largest working group (green cluster) with 11 authors are located in the middle of the graphic and have more corporation with other researchers, which include Maccormack M. Luke, Norby Richard J. The second larger group (red cluster) was also with 11 authors, including Brunner Ivano and Makita Naoki. The third group (blue cluster) was eight authors mainly connected by Chen HYH. The fourth group was six authors mainly including Fahey Timothy J and Guo Dali. The fifth was five authors mainly from Estonia and Finland. The rest of the groups only consists of two or three authors, i.e., the top productive authors Leuschner C and Hertel D form 
a group, and Pregitzer KS and Zak DR form another group. Some Chinese authors were clustered into collaboration groups (Figure 2). Moreover, Maccormack M. Luke, Guo Dali, Helmisaari HS, Ostonen Ivika, Reich Peter B. and Hobbie, Sarah E are social bridges among authors (Figure 2). The authors' co-authorship network analyses reveal the international cooperation between authors from different nationalities; affiliations in current topics is still very weak.

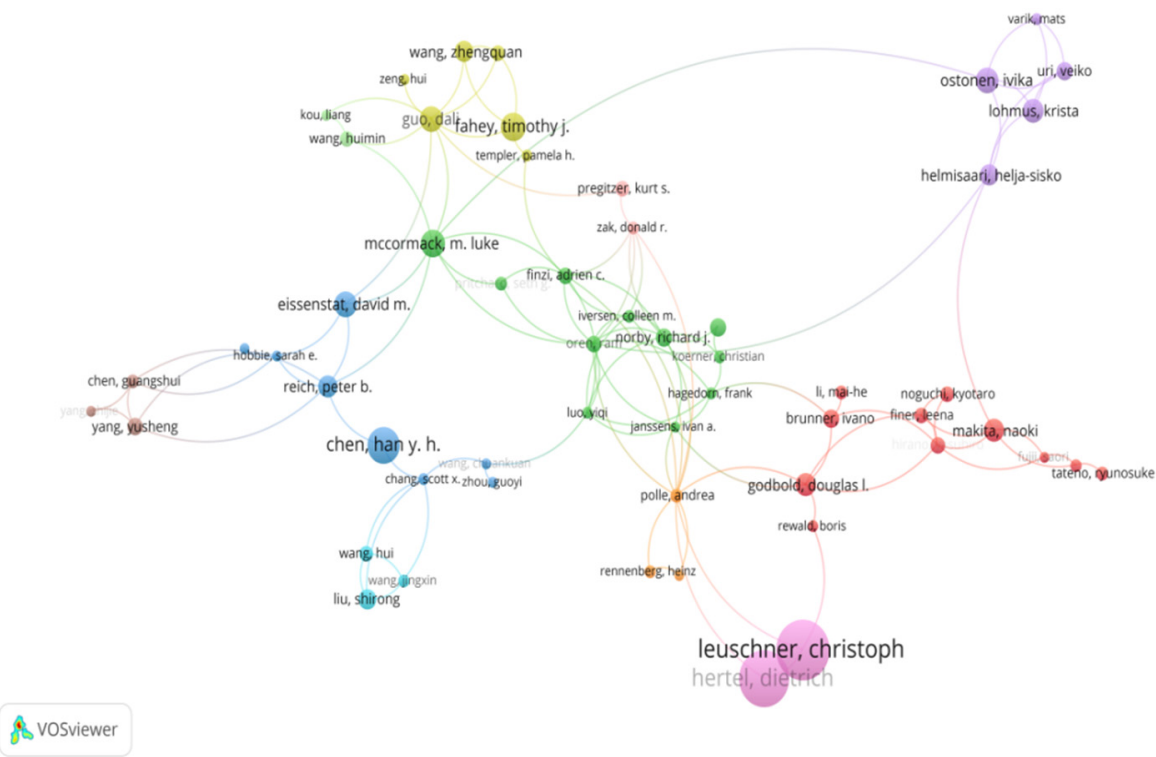

Figure 2. Authors' co-authorship network.

Moreover, the institutions and countries cooperation network showed that close collaborative relationships were identified between institutions within each country (Figure S3). Chinese Academy of Sciences, United States Forest Service and University of Chinese Academy of Sciences made greater contributions on corporation with other institutions. Chinese Academy of Sciences made the obvious efforts on promoting cooperation both domestically and internationally (Figure S4a). Among the selected top 50 cooperation institutions, Chinese Academy of Sciences had 306 collaborative publications with the others 26 institutions, but mainly with domestic institutions (89 and 21 collaborative publications with University of Chinese Academy of Sciences and Northwest A\&F University, respectively). Similarly, countries in the same continent or in a union have more cooperation research. Top 30 cooperation counties based on total link strength can be grouped into three clusters (Figure S4b). The red cluster with 19 countries mainly included European countries, Japan, and Russia. The green cluster with 9 countries mainly included USA, England, Australia, and France. The blue cluster only had China and Canada. The countries with the most frequent contributions include USA, Germany, and China. The USA played a core role in the collaborative network with others 28 countries. The link strength between USA and China is the maximum, followed by USA-England, USA-Canada, USA-Germany, and USA-Australia (Figure S4b).

\subsection{Co-Citation Network Analysis}

Co-citation is a bibliographic analysis method that indicates a connection between two documents that are both cited by an identical third document [37] (van Eck \& Waltman, 2010). Co-citation analysis, including cited references, cited sources, and cited authors, is to explore the most influential publications, journals, and authors in an area. In a co-citation network, a cluster can be defined as a group of well-connected publications in a research area with limited connections to publications of other clusters or research areas.

Among the 83,666 cited references, a co-citation network of top 50 influential publications was presented based on the calculated total strength of the co-citation links with other cited references. Jackson et al. (1997) [6], Pregitzer et al. (2002) [45], Gill and Jack- 
son (2000) [46] are the top influence co-citation documents (Table 3, Figure 3a). When publications in the reference lists were mapped, three clusters were apparent (Figure 3a). The red cluster one with 23 publications (from 1997 to 2015) focuses on fine root life span $[6,14,47,48]$, turnover $[46,49,50]$, and branch order $[51,52]$. The green cluster with 19 publications includes the foundational publications for fine root biomass distribution and dynamics, especially in northern hardwood forests [3,40,53-56], while the blue cluster with 8 publications (from 1989 to 2001) contained research on the contribution of fine respiration to soil respiration [57-60].

a

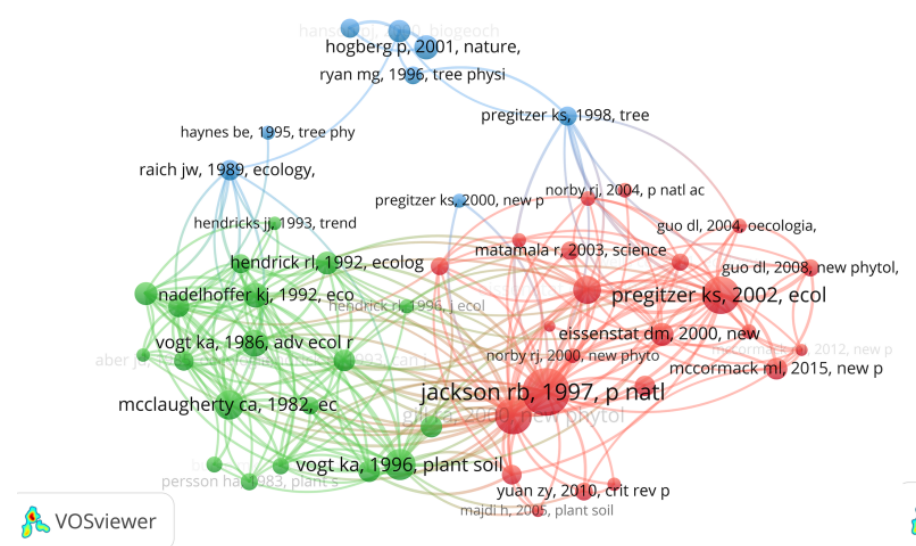

b

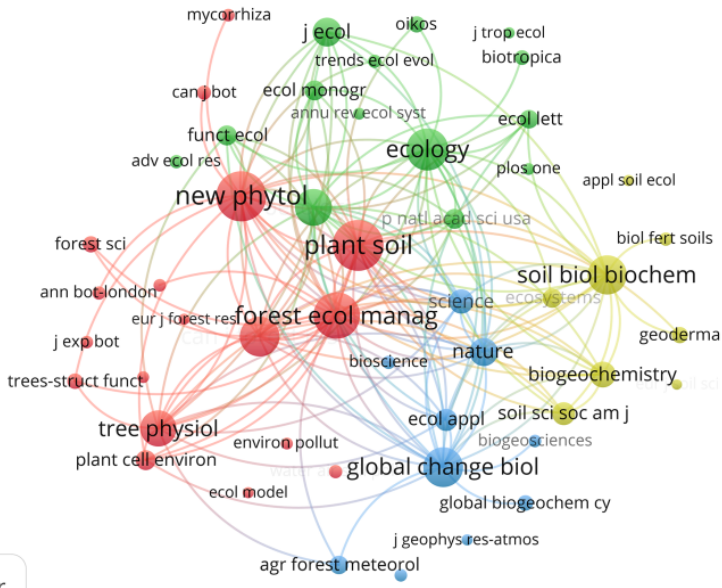

Figure 3. The most co-cited publications (a) and journals (b) network analysis.

The distance between two journals in the visualization of journal co-citation indicates the relatedness between various journals and disciplines. In general, the closer two journals are located to each other, the stronger is their relatedness. The journal co-citation network for this study shows four major clusters of journals (Figure 3b): plant science and forestry in the red cluster (e.g., Plant and Soil, New Phytologist, Forest Ecology and Management, Canadian Journal of Forest Research, Plant Cell and Environment, Tree Physiology,), environmental sciences and multidisciplinary sciences in blue cluster (e.g., Nature, Science, Global Change Biology, Ecological Applications), ecology in green cluster (e.g., Ecology, Trends in Ecology and Evolution, Ecology Letters, Ecology, Functional) and soil science in yellow cluster (e.g., Soil Biology and Biochemistry, Soil Science Society of America Journal, Geoderma). Plant and Soil, New Phytologist, and Forest Ecology and Management are the journals cited with the highest cited frequency (with 10,387, 10,174 and 8745 citations, respectively) (Figure 3b). Moreover, Vogt, Ka and Pregitzer, Ks are the most co-cited authors (with 1312 and 1194 citations, respectively) (Table 1). The top ten co-cited authors were from USA, indicating the strongest academic influence of fine roots research in USA. Although China had the higher number of papers related to fine roots research, especially for Chinese Academy of Sciences as the highest institute (Table 1), there were no high-yield authors and co-cited authors from China (Table 2). Therefore, Chinese researchers should strengthen cooperation with foreign scholars and find innovative research methods to improve the quality of papers and the academic influence of fine root research in China.

\subsection{Keyword Analysis}

To capture the hot issues and identify the research trends in scientific research, the bibliometric method through keywords analysis (mainly including author keywords and keywords plus) is often selected in many previous studies [24,31]. Author keywords can offer important information about the core content and research trends from a researcher's point of view, while keywords plus are generated by an ISI algorithm, from words or expressions of the article's reference titles. Except for the search words in this study, the two most frequently used author keywords were "soil respiration" and "nitrogen" and the 
most frequently used keywords plus were "dynamics" and "growth" (Table 5). "Biomass", "nitrogen", "decomposition", and "carbon" were commonly used in both author keywords and keywords plus (Table 5). Tree species "picea abies" was a frequently used author keyword and "norway spruce" was in keywords plus (Table 5). The annual occurrences of these keywords have different dynamics trends during the recorded period (Figure S5). The occurrences of "soil respiration" obviously increased from 1992 and reached a plateau around 2012 and then kept increasing almost steadily. The great importance of "climate change" has been attached to fine root research after 2010 (Figure S5). The annual occurrences of most keywords plus (excluding turn over and organic matter) obviously increased during the whole study period (Figure S5).

Table 5. The top 20 frequency of author keywords and keywords plus used during 1992-2020.

\begin{tabular}{ccccc}
\hline Rank & Author Keywords & Occurrences & Keywords Plus & Occurrences \\
\hline 1 & fine roots & 336 & dynamics & 637 \\
2 & soil respiration & 178 & growth & 556 \\
3 & nitrogen & 157 & forest & 491 \\
4 & fine root & 127 & biomass & 480 \\
5 & decomposition & 109 & nitrogen & 439 \\
6 & fine root biomass & 106 & fine roots & 427 \\
7 & biomass & 97 & carbon & 353 \\
8 & climate change & 95 & organic-matter & 331 \\
9 & minirhizotron & 87 & turnover & 327 \\
10 & picea abies & 86 & soil & 314 \\
11 & carbon & 78 & ecosystems & 282 \\
12 & root biomass & 76 & norway spruce & 254 \\
13 & phosphorus & 68 & patterns & 220 \\
14 & drought & 63 & responses & 205 \\
15 & production & 63 & decomposition & 201 \\
16 & roots & 63 & respiration & 185 \\
17 & soil carbon & 63 & net primary & 177 \\
18 & carbon & 62 & production & \\
& sequestration & 60 & fine-root & 175 \\
19 & carbon allocation & 60 & litter & 161 \\
20 & specific root length & 60 & productivity & 160 \\
\hline \multirow{2}{*}{} & & &
\end{tabular}

Moreover, cluster analysis can not only help to gather related keywords, but also reflect the close relationship between keywords [24,31]. The network visualization map of co-occurrence author keywords, excepting the search words obtained through VOSviewer (obtained considering 20 as the minimum number of occurrences of a keyword) shows that the Cluster 1 represents the largest cluster with 25 keywords, focused on "fine root biomass" "ectomycorrhizal", "specific root length" of "root traits" for "eucalyptus", "fagus sylvatica", "norway spruce", "picea abies", and "pinus sylvestris" (Figure 4). Custer 2 had 21 items, referred to the effect of "decomposition" with keywords of "litter decomposition", "litter quality", "microbial biomass", "soil organic matter", "nitrification" with "15 N" method mainly in "loblolly pine" species, "temperate forest". Cluster 3 had 19 terms, focused on "carbon sequestration" with keywords of "carbon allocation", "carbon storage", "aboveground biomass", "belowground biomass", "net primary production", , fine root production", "fine root turnover", "litterfall", "soil organic carbon", "soil nutrients" with the "stand age" and "succession" development of "afforestation" plantations and " boreal forest". Cluster 4 had 13 items, focused on "soil respiration" such as "autotrophic respiration", "heterotrophic respiration", "root respiration", and "soil $\mathrm{CO}_{2}$ efflux" under "climate change", i.e., "elevated CO2", "drought", "nitrogen addition". Cluster 5 had 11 items, focused on using the "minirhizontron" method to study fine root "production", "turnover", "mortality", "seasonality". Cluster 6 had 6 items, focused on the effects 
of "nutrient limitation" and "fertilization", such as "carbon", "nitrogen", "phosphorus" and "calcium".

\section{禹 VoSviewer}

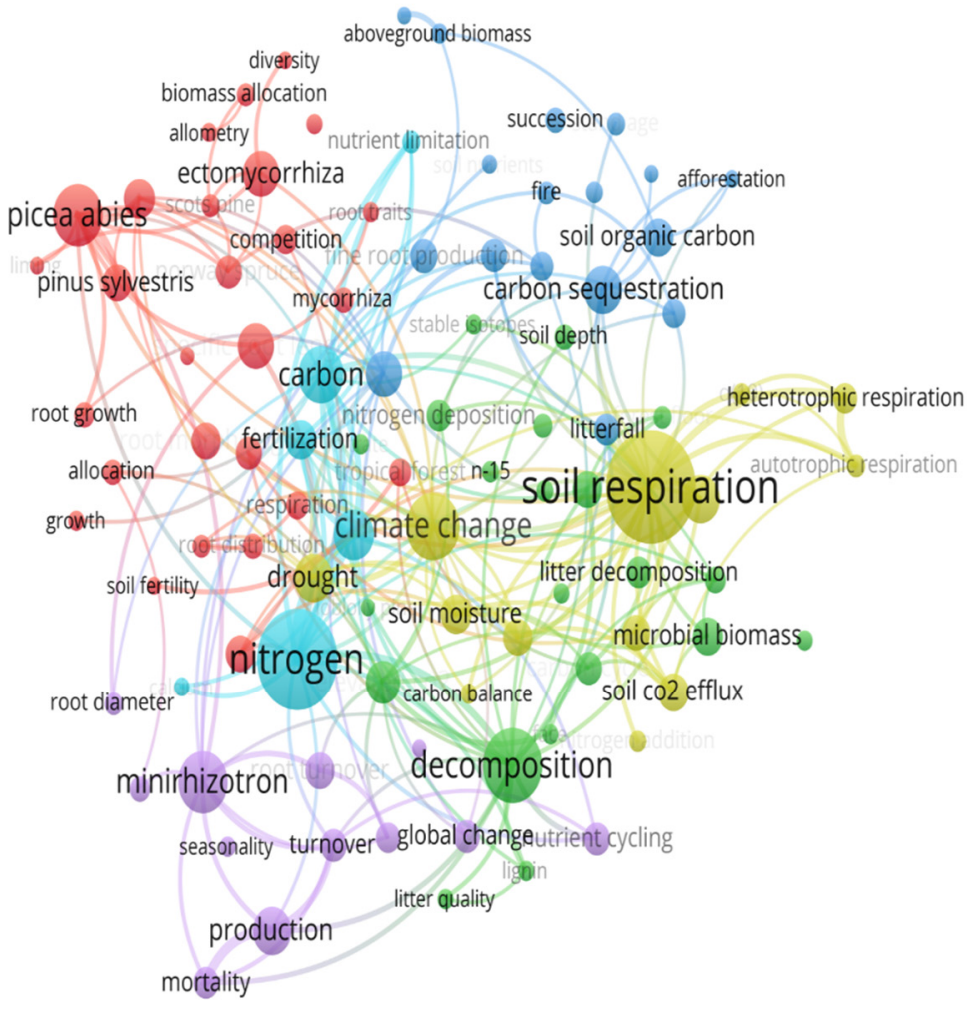

Figure 4. Co-occurrence of keywords clusters.

In addition, the trend topics based on the annual frequency of keywords analyses showed that research on fine roots in forests were at an initial stage before 2000 (Figure 5). The frequency of keywords, i.e., root mass, dry matter production, and demography, was rather low. However, there were many classical papers published during this period (Table 3). The frequency of keywords significantly increased after 2000 (Figure 5). The main research interests focus on fine root growth and mycorrhizas with soil nutrients, especially for nitrogen mineralization and acidification, from 2000 to 2006. The research topics reached the maximum plateau stage from 2006 to 2017. The top frequency of keywords commonly occurred during this period (Table 5 and Figure 5). As mentioned before, biomass, decomposition, respiration, climate change, carbon sequestration, and others were hot topics from 2006 to 2017. "Nitrogen addition", "ecological stoichiometry", "absorptive roots", and "root exudates" are hot topics from 2018 to now (Figure 5).

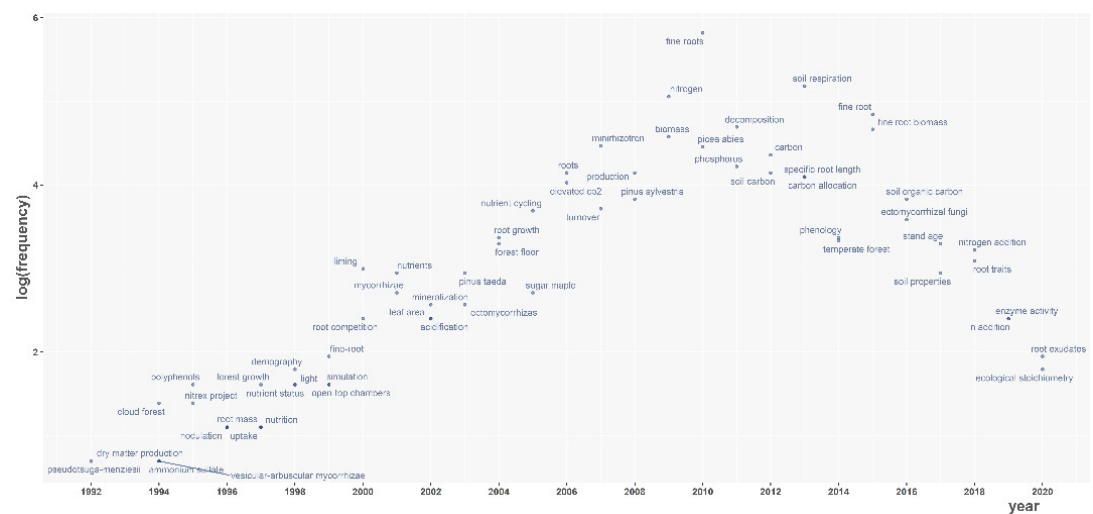

Figure 5. The research trend topics of fine roots research on forest ecosystem. 


\section{Conclusions and Future Perspectives}

The critical functions of fine roots in forest ecosystems have attracted global attention. Despite their importance, fine roots remain amongst the least understood components of forest ecosystems. This study provides a bibliometric analysis on global research overview of fine roots in forest ecosystems with information related to countries, institutions, journals, top cited publications, authors, hot issues, and research trends. The related publications increased with the Price law from 1992 to 2020. USA, China, and Germany had high productivity in total publications. Chinese Academy of Sciences, United States Forest Service, and Swedish University of Agricultural Science were the top productivity institutions. Plant and Soil, Forest Ecology and Management, Soil Biology Biochemistry, Global Change Biology, New Phytologist, and Tree Physiology were confirmed as the core journals from 471 journals based on Bradford's law. The most productive authors and the top cited and co-cited articles were identified. However, the author collaboration network was very weak. Based on keyword clustering analysis, research trends have changed during the last 30 years, and the main research hotspots are fine roots biomass, decomposition, and respiration, especially under climate change.

Although the current study has made a comprehensive view on fine roots research in forest ecosystems from a large database, it also has some limitations, like previous bibliometric analyses. First, common challenges with bibliometric analysis include criteria for selecting publications and datasets. Although the Web of Science database contains the widest scope of studies, it may omit some relevant research on the topic. Multisource searching among different databases, such as Google Scholar and Scopus, would be more convincing in future analyses. Moreover, some countries have their own language databases, i.e., China National Knowledge Infrastructure (CNKI) database in China. Cross-comparison studies among country-specific databases would better understand the different research status and hot topics in individual countries. Second, we identified that scientific research development, main themes, and evolution are based on the quantifying details of 3310 publications, but does not provide more detailed information, such as the methodologies, theoretical background, and the main findings of each work. Therefore, there is the need to merge with content analysis for more in-depth analysis. Finally, bibliometric tools, i.e., VOSviewer, CiteSpace, and bibliometrix, have their own function limitations, although they have been used for many bibliometric research studies. Due to different algorithms and mapping techniques, their results are incompatible with each other to some extent. Moreover, promising potential new tools, i.e., machine learning, will enable interaction with bibliometric studies to deal with the enormous increase in available text. Machine learning allows approaches to overcome the time-consuming search of a large numbers of studies and to enhance the accuracy of information extraction.

Moreover, it should be made aware that other important issues were not addressed due to the limitation of software and the retrieved database. We suggest that it is also valuable to focus on the following key issues and research questions as priorities in future, including: (1) new destructive and non-destructive methods are needed for studies of fine root traits and their functions, and the uncertainty and inaccuracy would needed to be assessed among different methods; (2) the kinetics and models of nutrient and water uptake by fine roots and the tools to scale up roots, individuals, ecosystem, and biosphere; (3) the dynamics interaction of fine roots and soil microbes and their effects on water, carbon, and nutrient cycling across space and time; (4) the interactions between belowground and aboveground components.

Supplementary Materials: The following supporting information can be downloaded at: https: / / www.mdpi.com/article/10.3390/f13010093/s1, Figure S1: the diagram of the study process; Figure S2: The top ten authors' production over the time; Figure S3: The annual publication of the top ten most productive journals; Figure S4: The cooperation network of institutions (a) and countries (b); Figure S5: The annual occurrences of high-frequency author keywords (a) and keyword plus (b). 


\begin{abstract}
Author Contributions: Conceptualization, Y.C.; methodology, L.H. and Z.X.; validation, Y.C.; formal analysis, Z.X.; writing—original draft preparation, L.H.; writing—review and editing, Y.C. All authors have read and agreed to the published version of the manuscript.
\end{abstract}

Funding: This work was supported by the National Nature Science Foundation of China (grant numbers No. 41977418 and 42130717); and CAS "Light of West China" Program (grant number XAB2017A02); and National Key R\&D Program of China (grant numbers 2016YFC0501703 and 2017YFC0504605)

\title{
Institutional Review Board Statement: Not applicable.
}

Informed Consent Statement: Not applicable.

Data Availability Statement: Dataset and associated codes used in the main results are available upon reasonable request to the corresponding author.

Acknowledgments: We would like to thank Kailiang Yu (High Meadows Environmental Institute, Princeton University, USA) for research assistance, and many thanks to those that participated in the project or helped in data collection.

Conflicts of Interest: The authors declare no conflict of interest.

\section{References}

1. Aleixandre-Benavent, P.; Aleixandre-Tudó, J.L.; Castelló-Cogollos, L.; Aleixandre, J.L. Trends in scientific research on climate change in agriculture and forestry subject areas (2005-2014). J. Clean. Prod. 2017, 147, 406-418. [CrossRef]

2. Andreo-Martinez, P.; Ortiz-Martinez, V.M.; Garcia-Martinez, N.; Lopez, P.P.; Quesada-Medina, J.; Camara, M.A.; Oliva, J. A descriptive bibliometric study on bioavailability of pesticides in vegetables, food or wine research (1976-2018). Environ. Toxicol. Pharmacol. 2020, 77, 103374. [CrossRef]

3. Aria, M.; Cuccurullo, C. bibliometrix: An R-tool for comprehensive science mapping analysis. J. Informetr. 2017, 11, 959-975. [CrossRef]

4. Biresselioglu, M.E.; Demir, M.H.; Solak, B.; Kayacan, A.; Altinci, S. Investigating the trends in arctic research: The increasing role of social sciences and humanities. Sci. Total Environ. 2020, 729, 139027. [CrossRef] [PubMed]

5. Cao, Y.; Li, Y.N.; Zhang, G.Q.; Zhang, J.; Chen, M. Fine root C:N:P stoichiometry and its driving factors across forest ecosystems in northwestern China. Sci. Total Environ. 2020, 737, 140299. [CrossRef]

6. Clemmensen, K.E.; Bahr, A.; Ovaskainen, O.; Dahlberg, A.; Ekblad, A.; Wallander, H.; Stenlid, J.; Finlay, R.D.; Wardle, D.A.; Lindahl, B.D. Roots and Associated Fungi Drive Long-Term Carbon Sequestration in Boreal Forest. Science 2013, 339, $1615-1618$. [CrossRef] [PubMed]

7. Cudlin, P.; Kieliszewska-Rojucka, B.; Rudawska, M.; Grebenc, T.; Alberton, O.; Lehto, T.; Bakker, M.R.; Borja, I.; Konopka, B.; Leski, T.; et al. Fine roots and ectomycorrhizas as indicators of environmental change. Plant Biosyst. 2007, 141, 406-425. [CrossRef]

8. Ding, Y.Y.; Leppalammi-Kujansuu, J.; Helmisaari, H.S. Fine root longevity and below- and aboveground litter production in a boreal Betula pendula forest. For. Ecol. Manag. 2019, 431, 17-25. [CrossRef]

9. Eissenstat, D.M.; Wells, C.E.; Yanai, R.D.; Whitbeck, J.L. Building roots in a changing environment: Implications for root longevity. New Phytol. 2000, 147, 33-42. [CrossRef]

10. Eissenstat, D.M.; Yanai, R.D. The ecology of root lifespan. Adv. Ecol. Res. 1997, 27, 1-60.

11. Eldhuset, T.D.; Kjonaas, O.J.; Lange, H. Decomposition rates and nutrient dynamics of Picea abies needles, twigs and fine roots after stem-only harvesting in eastern and western Norway. Plant Soil 2017, 418, 357-375. [CrossRef]

12. Finér, L.; Ohashi, M.; Noguchi, K.; Hirano, Y. Factors causing variation in fine root biomass in forest ecosystems. For. Ecol. Manag. 2011, 261, 265-277. [CrossRef]

13. Freschet, G.T.; Cornwell, W.K.; Wardle, D.A.; Elumeeva, T.G.; Liu, W.D.; Jackson, B.G.; Onipchenko, V.G.; Soudzilovskaia, N.A.; Tao, J.P.; Cornelissen, J.H.C. Linking litter decomposition of above- and below-ground organs to plant-soil feedbacks worldwide. J. Ecol. 2013, 101, 943-952. [CrossRef]

14. Germon, A.; Laclau, J.P.; Robin, A.; Jourdan, C. Tamm Review: Deep fine roots in forest ecosystems: Why dig deeper? For. Ecol. Manag. 2020, 466, 118135. [CrossRef]

15. Gill, R.A.; Jackson, R.B. Global patterns of root turnover for terrestrial ecosystems. New Phytol. 2000, 147, 13-31. [CrossRef]

16. Gower, S.T.; Pongracic, S.; Landsberg, J.J. A global trend in belowground carbon allocation: Can we use the relationship at smaller scales? Ecology 1996, 77, 1750-1755. [CrossRef]

17. Guo, D.; Mitchell, R.; Hendricks, J. Fine root branch orders respond differentially to carbon source-sink manipulations in a longleaf pine forest. Oecologia 2004, 140, 450-457. [CrossRef]

18. Guo, D.L.; Li, H.; Mitchell, R.J.; Han, W.X.; Hendricks, J.J.; Fahey, T.J.; Hendrick, R.L. Fine root heterogeneity by branch order: Exploring the discrepancy in root turnover estimates between minirhizotron and carbon isotopic methods. New Phytol. 2008, 177, 443-456. [CrossRef] 
19. Hanson, P.J.; Edwards, N.T.; Garten, C.T.; Andrews, J.A. Separating root and soil microbial contributions to soil respiration: A review of methods and observations. Biogeochemistry 2000, 48, 115-146. [CrossRef]

20. Hendricks, J.J.; Nadelhoffer, K.J.; Aber, J.D. Assessing the role of fine roots in carbon and nutrient cycling. Trends Ecol. Evol. 1993, 8, 174-178. [CrossRef]

21. Hendricks, J.J.; Hendrick, R.L.; Wilson, C.A.; Mitchell, R.J.; Pecot, S.D.; Guo, D.L. Assessing the patterns and controls of fine root dynamics: An empirical test and methodological review. J. Ecol. 2006, 94, 40-57. [CrossRef]

22. Hendrick, R.L.; Pregitzer, K.S. The demography of fine roots in a northern hardwood forest. Ecology 1992, 73, 1094-1104 [CrossRef]

23. Hong, T.; Feng, X.Z.; Tong, W.W.; Xu, W.D. Bibliometric analysis of research on the trends in autophagy. PeerJ 2019, 7, e7103 [CrossRef] [PubMed]

24. Huang, L.; Zhou, M.; Lv, J.; Chen, K. Trends in global research in forest carbon sequestration: A bibliometric analysis. J. Clean. Prod. 2020, 252, 1199008. [CrossRef]

25. Iversen, C.M.; McCormack, M.L.; Powell, A.S.; Blackwood, C.B.; Freschet, G.T.; Kattge, J.P.M.; Violle, C. A global Fine-Root Ecology Database to address below-ground challenges in plant ecology. New Phytol. 2017, 215, 15-26. [CrossRef]

26. Jackson, R.B.; Canadell, J.; Ehleringer, J.R.; Mooney, H.A.; Sala, O.E.; Schulze, E.D. A global analysis of root distributions for terrestrial biomes. Oecologia 1996, 108, 389-411. [CrossRef] [PubMed]

27. Jackson, R.B.; Mooney, H.A.; Schulze, E.D. A global budget for fine root biomass, surface area, and nutrient contents. Proc. Natl. Acad. Sci. USA 1997, 94, 7362-7366. [CrossRef]

28. Johnson, M.G.; Tingey, D.T.; Phillips, D.L.; Storm, M.J. Advancing fine root research with minirhizotrons. Environ. Exp. Bot. 2001, 45, 263-289. [CrossRef]

29. Kulak, M.; Ozkan, A.; Bindak, R. A bibliometric analysis of the essential oil-bearing plants exposed to the water stress: How long way we have come and how much further? Sci. Hortic. 2019, 246, 418-436. [CrossRef]

30. Liu, Y.N.; Wu, K.N.; Zhao, R. Bibliometric analysis of research on soil health from 1999 to 2018. J. Soils Sediments 2020, 20, 1513-1525. [CrossRef]

31. Ma, Q.; Zhang, Y. Global Research Trends and Hotspots on Submarine Groundwater Discharge (SGD): A Bibliometric Analysis. Int. J. Environ. Res. Public Health 2020, 17, 830. [CrossRef]

32. Majdi, H.; Pregitzer, K.; Moren, A.S.; Nylund, J.E.; Agren, G.I. Measuring fine root turnover in forest ecosystems. Plant Soil 2005, 276, 1-8. [CrossRef]

33. Matamala, R.; Gonzalez-Meler, M.A.; Jastrow, J.D.; Norby, R.J.; Schlesinger, W.H. Impacts of Fine Root Turnover on Forest NPP and Soil C Sequestration Potential. Science 2003, 302, 1385-1387. [CrossRef] [PubMed]

34. McCormack, M.L.; Adams, T.S.; Smithwick, E.A.; Eissenstat, D.M. Predicting fine root lifespan from plant functional traits in temperate trees. New Phytol. 2012, 195, 823-831. [CrossRef]

35. McCormack, M.L.; Dickie, I.A.; Eissenstat, D.M.; Fahey, T.J.; Fernandez, C.W.; Guo, D.L.; Helmisaari, H.S.; Hobbie, E.A.; Iversen, C.M.; Jackson, R.B.; et al. Redefining fine roots improves understanding of below-ground contributions to terrestrial biosphere processes. New Phytol. 2015, 207, 505-518. [CrossRef]

36. Mourao, P.R.; Martinho, V.D. Forest entrepreneurship: A bibliometric analysis and a discussion about the co-authorship networks of an emerging scientific field. J. Clean. Prod. 2020, 256, 120413. [CrossRef]

37. Nadelhoffer, K.J.; Raich, J.W. Fine root production estimates and belowground carbon allocation in forest ecosystems. Ecology 1992, 73, 1139-1147. [CrossRef]

38. Norby, R.J.; Jackson, R.B. Root dynamics and global change: Seeking an ecosystem perspective. New Phytol. 2000, 147, 3-12. [CrossRef]

39. Ostonen, I.; Puttsepp, U.; Biel, C.; Alberton, O.; Bakker, M.R.; Lohmus, K.; Majdi, H.; Metcalfe, D.; Olsthoorn, A.F.M.; Pronk, A.; et al. Specific root length as an indicator of environmental change. Plant Biosyst. 2007, 141, 426-442. [CrossRef]

40. Palviainen, M.; Finer, L.; Kurka, A.M.; Mannerkoski, H.; Piirainen, S.; Starr, M. Decomposition and nutrient release from logging residues after clear-cutting of mixed boreal forest. Plant Soil 2004, 263, 53-67. [CrossRef]

41. Pregitzer, K.S.; DeForest, J.L.; Burton, A.J.; Allen, M.F.; Ruess, R.W.; Hendrick, R.L. Fine root architecture of nine North American trees. Ecol. Monogr. 2002, 72, 293-309. [CrossRef]

42. Pregitzer, K.S.; King, J.A.; Burton, A.J.; Brown, S.E. Responses of tree fine roots to temperature. New Phytol. 2000, 147, 105-115. [CrossRef]

43. Pregitzer, K.S.; Laskowski, M.J.; Burton, A.J.; Lessard, V.C.; Zak, D.R. Variation in sugar maple root respiration with root diameter and soil depth. Tree Physiol. 1998, 18, 665-670. [CrossRef]

44. Reich, P.B. The world-wide 'fast-slow' plant economics spectrum: A traits manifesto. J. Ecol. 2014, 102, 275-301. [CrossRef]

45. Ryan, M.G.; Hubbard, R.M.; Pongracic, S.; Raison, R.J.; McMurtrie, R.E. Foliage, fine-root, woody-tissue and stand respiration in Pinus radiata in relation to nitrogen status. Tree Physiol. 1996, 16, 333-343. [CrossRef] [PubMed]

46. Steele, S.J.; Gower, S.T.; Vogel, J.G.; Norman, J.M. Root mass, net primary production and turnover in aspen, jack pine and black spruce forests in Saskatchewan and Manitoba, Canada. Tree Physiol. 1997, 17, 577-587. [CrossRef]

47. Silver, W.L.; Miya, R.K. Global patterns in root decomposition: Comparisons of climate and litter quality effects. Oecologia 2001, 129, 407-419. [CrossRef] 
48. Su, Y.A.; Yu, Y.N.; Zhang, N. Carbon emissions and environmental management based on Big Data and Streaming Data: A bibliometric analysis. Sci. Total Environ. 2020, 733, 138984. [CrossRef] [PubMed]

49. Torres, R.T.; Fernandes, J.; Carvalho, J.; Cunha, M.V.; Caetano, T.; Mendo, S.; Serrano, E.; Fonseca, C. Wild boar as a reservoir of antimicrobial resistance. Sci. Total Environ. 2020, 717, 135001. [CrossRef]

50. Van Eck, N.J.; Waltman, L. Software survey: VOSviewer, a computer program for bibliometric mapping. Scientometrics 2010, 84, 523-538. [CrossRef] [PubMed]

51. Vargas, S.A.; Esteves, G.R.T.; Macaira, P.M.; Bastos, B.Q.; Oliveira, F.L.C.; Souza, R.C. Wind power generation: A review and a research agenda. J. Clean. Prod. 2019, 218, 850-870. [CrossRef]

52. Vogt, K.A.; Grier, C.C.; Vogt, D.J. Production, Turnover, and Nutrient Dynamics of Above- and Belowground Detritus of World Forests. Adv. Ecol. Res. 1986, 15, 303-377.

53. Vogt, K.A.; Vogt, D.J.; Palmiotto, P.A.; Boon, P.; O’Hara, J.; Asbjornsen, H. Review of root dynamics in forest ecosystems grouped by climate, climatic forest type and species. Plant Soil 1995, 187, 159-219. [CrossRef]

54. Wan, R.; Li, L.; Peng, R.G.; Gao, L. Worldwide scientific productions with immunotherapy of sepsis: A bibliometric analysis. PeerJ 2019, 7, e7116. [CrossRef]

55. Weemstra, M.; Mommer, L.; Visser, E.J.W.; van Ruijven, J.; Kuyper, T.W.; Mohren, G.M.J.; Sterck, F.J. Towards a multidimensional root trait framework: A tree root review. New Phytol. 2016, 211, 1159-1169. [CrossRef] [PubMed]

56. Xia, J.Y.; Wang, J.; Niu, S.L. Research challenges and opportunities for using big data in global change biology. Global Change Biol. 2020, 26, 6040-6061. [CrossRef] [PubMed]

57. Yuan, Z.Y.; Chen, H.Y.H. Fine Root Biomass, Production, Turnover Rates, and Nutrient Contents in Boreal Forest Ecosystems in Relation to Species, Climate, Fertility, and Stand Age: Literature Review and Meta-Analyses. Crit. Rev. Plant Sci. 2010, 29, 204-221. [CrossRef]

58. Zhang, Y.; Chen, Y.P. Research trends and areas of focus on the Chinese Loess Plateau: A bibliometric analysis during 1991-2018. Catena 2020, 194, 104798. [CrossRef]

59. Zhang, Y.; Huang, K.; Yu, Y.J.; Yang, B.B. Mapping of water footprint research: A bibliometric analysis during 2006-2015. J. Clean. Prod. 2017, 149, 70-79. [CrossRef]

60. Zhang, Y.; Pu, S.Y.; Lv, X.; Gao, Y.; Ge, L. Global trends and prospects in microplastics research: A bibliometric analysis. J. Hazard. Mater. 2020, 400, 123110. [CrossRef] 